\title{
The Relationship between Information Asymmetry and the Quality of Audit: An Empirical Study in Istanbul Stock Exchange
}

\author{
İdiris Varıc $1^{1}$ \\ ${ }^{1}$ The Faculty of Economics and Business Administration, Ondokuzmayıs University, Turkey. \\ Correspondence: The Faculty of Economics and Business Administration, Ondokuzmayis University, Samsun, \\ Turkey. Tel: 90-362-312-1919. E-mail: idris.varici@omu.edu.tr
}

Received: July 1, 2013

Accepted: July 19, 2013

Online Published: September 23, 2013

doi:10.5539/ibr.v6n10p132

URL: http://dx.doi.org/10.5539/ibr.v6n10p132

\begin{abstract}
Information asymmetry occurs where one party of an enterprise has more or better information than the other. The primary objective is to remove asymmetric information. It is argued that information asymmetry can be removed by a high quality audit. This study examined the differences between the enterprises audited by Big Four audit companies that were employed for measuring the quality of audit and the enterprises not put into such audit in terms of information asymmetry variables. The enterprises audited by four big audit companies, which were argued to make a high quality audit, were compared with other enterprises in terms of 6 variables used in the measurement of information asymmetry. The study was conducted on manufacturing industry enterprises traded at Istanbul Stock Exchange (Note 1). The variables of the independence of the board of directors, market value/book value, and Tobin $\mathrm{Q}$ were found to be statistically different in two separate enterprise groups. However, the study yielded results contrary to those reported in the literature.
\end{abstract}

Keywords: audit quality, information asymmetry, big four audit company

\section{Introduction}

Information asymmetry appears where one investor or several investors has/have confidential information about the value of an enterprise while most of investors have only the publicly available information (Brown \& Hillegeist, 2007). The aforesaid informed investors are mostly from top management. This is because; there is not an intense flow of information from enterprises to markets. Therefore, it is not possible to remove information asymmetry completely. However, the primary objective is to minimize information asymmetry because it affects the decisions to be taken by the third parties in regard to an enterprise. The information asymmetry between managers and investors as well as other third parties can be reduced if information level goes up.

Finance literature contains various suggestions for reducing information asymmetry. However, these suggestions are mostly about the increased information presentation or voluntary information disclosure by the people from enterprises. Voluntary information disclosure is not common in countries with low transparency (e.g., Turkey). Thus, another motive should come into play so that an increased level of high quality information is disclosed. Independent audit can be one of the elements that may fulfill this function at least for now.

There is an information asymmetry between a client enterprise and an auditor in the auditing process. The employees and managers of an enterprise have clearer information about its structure and operation. An auditor is a third party who tries to verify the information provided by an enterprise management as far as possible. Thus, it is the auditor who has the most precise information about an enterprise after those who are already within the body of the enterprise. The purpose of the auditor is to verify the information provided by the enterprise management with a professional skepticism, which requires the auditor to act considering that the information provided by the management may be misleading. In this regard, audit's reports are of vital importance especially for the third parties because they allow reaching the exact information and enable disclosure of the information that must be revealed, but that has not been revealed yet. Therefore, auditor's opinion and the quality of this opinion are of great importance.

The main focus of this paper is on the relationship between information asymmetry and the quality of audit. Firstly, a literature review is presented in order to give information about the variables used for measuring 
information asymmetry. Then, the studies focusing on the relationship between information asymmetry and the quality of audit are provided. The final section of this paper shows the results obtained in this study dealing with the manufacturing industry enterprises traded at Istanbul Stock Exchange.

\section{Corporate Governance and Information Asymmetry}

Good governance at publicly held corporations especially where shareholders have a high risk to lose their assets reduces information asymmetry between shareholders and management. Voluntary disclosures by managers prevent the formation of information asymmetry between shareholders and management to a certain extent (Karamanou \& Vafeas, 2005). The principle of public disclosure, which is a must of corporate governance, is aimed at reducing information asymmetry. This principle can be associated with the establishment and implementation of audit mechanisms that are necessary for protecting investors in particular.

Information asymmetry creates unearned economic benefits for corporate managers and internal learners (Note 2 ), but deprives investors of many possible interests. Better corporate governance improves an enterprise's performance and market efficiency, and reduces information asymmetry. Good corporate governance may improve the market efficiency of an enterprise by reducing information asymmetry between managers and investors. If any information required to be disclosed to the public is hidden or deformed, investors will have difficulty in understanding investment risks. In such a case, investors may have difficulty in making a proper choice (Anglin, Edelstein, Gao, \& Tsang, 2011).

The existence of an audit committee is one of the important factors decreasing information asymmetry. The characteristic of an audit committee is very important in terms of the quality of the information to be disclosed to the public (Vafeas, 2005). For instance, the expert accountants included in an audit committee improve the effectiveness of corporate audit. This has a linear relationship with the increase in the quality of disclosed information and the decrease in information asymmetry (Krishnan \& Visvanathan, 2008). Furthermore, the independence of the audit committee and the qualification of financial experts functioning within the body of the audit committee contribute to the decrease of information asymmetry, too (Anglin et al., 2011).

In general terms, there is a relationship between information asymmetry and the quality of corporate governance. One of the requirements of corporate governance is a high quality management. A high quality management decreases information asymmetry, too (Berglund \& Westerholm, 2010). The number of independent members in top management is important in terms of the measurement of the quality of management.

\section{The Relationship between Information Asymmetry and Accounting Standards}

Countries have started to bring their accounting standards into conformity with international accounting standards as a result of the convergence of international accounting standards. This creates an environment vulnerable to exploitation by the financing decisions of enterprise managements in particular. For example, transition from domestic standards to international standards brings about changes in the disclosure of the financial position of an enterprise to customers, which may cause investors to raise the stock value of the enterprise. Moreover, since managers learn the possible effects of transition to international accounting standards earlier than investors, adaptation to IFRS creates an external effect for information asymmetry between managers and investors. Finally, the fact that implementation process continues for a while during transition to IFRS provides a long time for information asymmetry to emerge in the financial decision making processes (Wang \& Welker, 2011).

\section{The Variables Used for Measuring Information Asymmetry}

Various financial and non-financial variables are used for measuring information asymmetry. Among these variables, the important ones and the ones to be used in this study are described below.

One of the variables used for measuring information asymmetry is the Altman Z-score - a financial failure score (Paprocki \& Stone, 2004). Altman developed this formula by carrying out discriminant analyses on manufacturing industry enterprises in 1968. The formula contains a total of five (Note 3) ratios (Altman, 1968). According to this formula, the enterprises with a low Z-score have a financial difficulty. The enterprises going through a financial difficulty are expected to have poor quality information (Paprocki \& Stone, 2004), thus a high information asymmetry. It is a known fact that an increase occurs in bankruptcy ratios among companies during financial crisis periods, and millions of dollars are lost due to the misinformation of investors (Russ, Achilles, \& Greenfiald, 2009). Such misinformation is an indicator of the existence of information asymmetry, too.

Another variable used for measuring information asymmetry is market value/book value (Note 4) ratio (Clarke \& Shastri, 2000). If there is a high information asymmetry, the market value of a company becomes higher than its 
book value depending on growth opportunities (Paprocki \& Stone, 2004). Thus, we can make mention of a positive condition if the aforesaid value is low. When this value is low, investors want to invest in stocks.

Information asymmetry plays a crucial role in low liquidity, too. This causes enterprises to need external capital. This can be measured by liability ratio. The ratio of short-term liabilities plus long-term liabilities to total assets refers to liability ratio (Krishnaswami \& Subramaniam, 1999). The need of an enterprise for external borrowing gives rise to voluntary disclosures. The improvement of disclosures reduces information asymmetry, too (Paprocki \& Stone, 2004).

The last variable used for measuring information asymmetry is the set of investment opportunities. The managers of enterprises having a high growth rate are argued to be very knowledgeable about both the set of investment opportunities of their enterprises and the cash flows to be provided by assets in the future. Therefore, many studies have used the set of investment opportunities for measuring information asymmetry (Clarke \& Shastri, 2000). Various scales are used for measuring information asymmetry. In the present study, Tobin Q (Adam \& Goyal, 2000) ratio was used.

Increasing number of voluntary disclosures by management depending on corporate governance (Karamanou \& Vafeas, 2005), the existence and the independence of audit committee (Krishnan \& Visvanathan, 2008), and high quality of management (Berglund \& Westerholm, 2010) are among the factors reducing information asymmetry. These factors stand as non-financial variables that can be used for measuring information asymmetry. The existence and the independence of audit committee are quite important for increasing the quality of information and providing exact information (Jackson, Robinson, \& Shelton, 2009). Especially the independence of the board of directors is critical in terms of the quality of financial information (Quan, 2007). This is because; the independent members of the board of directors may act for the benefit of shareholders more as they do not have any management responsibility in the enterprise (Fanning \& Cogger, 1998). Audit committee and management play a key role in terms of the fulfillment of the need of third parties for information. Therefore, both are important for information asymmetry.

\section{The Relationship between Information Asymmetry and the Quality of Audit}

The financial structure and the operating results of an enterprise are important especially for those parties who are interested in this enterprise, but do not have any possibility to obtain direct information. The accuracy and the reliability of such information are as important as reaching it. Independent audit is needed in order to provide reliable information about the enterprise, and increase the degree of reliability of such information. Expected benefit can be gained from independent audit only if a high quality audit service is rendered (Kavut, 2001).

External auditors may provide appropriate environments to prevent probable conflicts of interest among managers and shareholders. The Enron scandal and other irregularities revealed recently have put the role of auditors in financial markets under microscope. Therefore, recent studies have dealt with the comparison of big audit companies and others in terms of the quality of audit in particular. These studies have fundamentally focused on the sizes of audit companies based on market perception and their specialties (Hakim \& Omri, 2009). Since the sizes of audit companies have been featured in the studies measuring the quality of audit, they are treated as a standard of quality in the present study, too.

Big audit companies have a low risk of being liable to a lawsuit because of their characteristics highlighted by quality. This is because; people or organizations need to embark on a quest to confirm that they have been wronged or resort to claiming their rights in order to bring a lawsuit. However, the communication of exact information to concerned people through a high quality auditing process can be accepted as an indicator of non-existence of injustice. Some studies support this, too. Palmrose (1988) stressed that fewer number of lawsuits were brought against Big Five audit companies in comparison to other audit companies because they rendered high quality audit services. On the other hand, Jones (2004) reported that big four audit companies started to provide higher quality audit services after the 1990s, and emphasized that the quality of audit in those audit companies was because of the experience and knowledge held by auditors working there. This is because; those who worked in those audit companies could comprehend the motives behind the information they acquired and analyze such information better thanks to the expertise they had (Knapp \& Knapp, 2001). In the case of Turkey, the quality of audit is poor especially in the enterprises with a risk of deception. Naturally, as the quality of audit increases, the risk of deception decreases (Varıc1, 2011).

Auditors guarantee investors that the financial statements of enterprises comply with generally accepted accounting principles and standards. In other words, auditors make an effort to demonstrate that financial statements are reliable, managers behave properly and honestly, and information about enterprises is reflected to the public exactly. Thus, information asymmetry is reduced when information level increases and true 
information is provided. It is reported by Leuz and Verrecchia (2000) and $\operatorname{Er}$ (2010) too. According to them, information asymmetry between managers and investors decreases as information level increases.

It is argued that information asymmetry plays an important role in the existence of audit organizations. The existence of information asymmetry between managers and enterprise owners has started to become a problem increasing the demand for auditors to function as an agent. A problem for auditors is that there is a high information asymmetry between managers and current enterprise owners as well as potential investors in regard to the market value of enterprise in the organizations where information is kept very confidential. Finally, there is an information asymmetry between current and potential investors and the auditors confirming financial statements (Simunic, 1990).

Literature review shows that auditors provide market participants with two important opportunities: knowledge and assurance. This is because; auditors independently audit (verify) the financial statements prepared by enterprise management and reveal any mistake (if any). In this way, a high quality audit contributes to the reliability of disclosed information. Thus, it helps reduce information asymmetry between concerned parties (Hakim \& Omri, 2010; Muller \& Riedl, 2002).

Recent research demonstrates that a high quality audit decreases information asymmetry and increases voluntary disclosures. For instance, according to Dunn and Mayhew (2004), a high quality audit decreases information asymmetry in a free market environment. Almutairi, Dunn and Skantz (2009) emphasize that there is a relationship between low information asymmetry and the terms of office and the specialty of auditors. These researchers state that high quality audit reduces information asymmetry and extends special information production for investors. In the present study, it was examined whether there was any information asymmetry difference between the enterprises audited by 4 big audit companies and the enterprises audited by other audit companies.

\section{Research}

\subsection{Goal and Scope}

The main purpose of this study was to determine whether there was any relationship between information asymmetry and the quality of audit, or to measure the information asymmetry levels of enterprises based on the quality of audit companies. In this respect, information asymmetry variables were examined in terms of the quality of audit. This is because; if a couple of investors hold special information about an enterprise while others do not, some different situations may emerge for this enterprise. For that reason, audit has a big importance for preventing enterprises from going beyond their primary objectives. The importance of audit can be measured by the quality of an audit company. The quality of an audit company can be measured by those audit companies which have proved themselves in the international arena. This is because; the auditors working in such audit companies are more knowledgeable, and can analyze the facts behind problems better (Knapp \& Knapp, 2001). Furthermore, these audit companies are bigger and can provide a more professional service. Therefore, it is expected for the enterprises audited by such audit companies to have lower information asymmetry.

\subsection{Data and Variables}

Data were acquired from the section titled "public disclosure platform" of Istanbul Stock Exchange's website. Data were acquired in 2011. Data for the year 2012 had not been published yet when this study was carried out. Data were about the manufacturing industry enterprises traded at Istanbul Stock Exchange. The reason for the choice of the year 2011 was that no extraordinary situation took place in that year. Those manufacturing industry enterprises about which sufficient data were not obtained were excluded from analysis. The study was conducted with 156 enterprises. According to the classification by Istanbul Stock Exchange, manufacturing industry enterprises are divided into 9 separate sectors. Table 1 shows the sub-sectoral distribution of manufacturing industry companies included in this study as well as relevant numbers.

As mentioned before, two kinds of variables were taken into consideration in this study: those aimed at measuring information asymmetry and those aimed at measuring the quality of audit. If an enterprise was audited by one of the 4 big audit companies (Note 5), it was deemed to receive a high quality audit service and was given 1 point. If an enterprise was audited by a company other than 4 big audit companies, it was considered to receive a poor quality audit service and was given 0 point. The following independent variables were used for measuring information asymmetry: the independence of audit committee (IAC), the highness of management quality (independence of the board of directors-IBD), Altman Z-score (AZ), the ratio of market value to book value (MV/BV), the ratio of short-term liabilities and long-term liabilities (total liabilities) to total assets (TL/TA), and 
Tobin Q ratio.

Table 1. Enterprises in terms of sub-sectors

\begin{tabular}{ll}
\hline Sub-Sector & Number of Enterprise \\
\hline Food, Beverage and Tobacco & 30 \\
Textile, Clothing and Leather & 26 \\
Forest Products and Furniture & 17 \\
Paper and Paper Products, Printing and Publishing & 30 \\
Chemistry, Petroleum, Rubber and Plastic Products & 29 \\
Stone and Soil Based & 16 \\
Metal Basic Industry & 32 \\
Metal Product, Machinery and Equipment & 3 \\
Others & $\mathbf{1 9 0}$ \\
Total Number of Enterprises & $(34)$ \\
Excluded from Analysis Due to the Lack of Data & $\mathbf{1 5 6}$ \\
Included in the Scope of Analysis & \\
\hline
\end{tabular}

\subsection{Methodology}

Mann-Whitney U test was used for detecting the relationship between information asymmetry and the quality of audit, i.e., for comparing information asymmetry variables based on the quality of audit. Mann-Whitney $U$ test is a non-parametric alternative of independent groups t-test. Since the values between two groups are turned into rank orders in this test, the original distributions of values are not important. Therefore, the use of these kinds of non-parametric tests is more suitable for studies in the field of social sciences in comparison to parametric tests.

\subsection{Findings}

The averages related to 6 variables that have been used in the literature for measuring information asymmetry are provided below under the assumptions that there is a high quality audit service and there is a low quality audit service. In addition, the averages of variables are provided in table 2 based on the total number of enterprises.

Table 2. Descriptive statistics

\begin{tabular}{|c|c|c|c|c|c|}
\hline Variables & Audit Quality & Number & Mean & Standard Deviation & General Mean \\
\hline \multirow[t]{2}{*}{ IAC } & Low & 81 & 0,3869 & 0,3104 & \multirow{2}{*}{0,41} \\
\hline & High & 75 & 0,4497 & 0,2544 & \\
\hline \multirow[t]{2}{*}{ IBD } & Low & 81 & 0,2725 & 0,1473 & \multirow{2}{*}{0,26} \\
\hline & High & 75 & 0,2523 & 0,1060 & \\
\hline \multirow[t]{2}{*}{$\mathrm{AZ}$} & Low & 81 & 2,7776 & 2,5496 & \multirow{2}{*}{2,90} \\
\hline & High & 75 & 3,0358 & 2,4210 & \\
\hline \multirow{2}{*}{$\mathrm{MV} / \mathrm{BV}$} & Low & 81 & 1,9249 & 2,3266 & \multirow{2}{*}{2,90} \\
\hline & High & 75 & 3,9618 & 13,3106 & \\
\hline \multirow{2}{*}{ TL/TA } & Low & 81 & 0,4384 & 0,2310 & \multirow{2}{*}{0,45} \\
\hline & High & 75 & 0,4722 & 0,2099 & \\
\hline \multirow{2}{*}{ TQ } & Low & 81 & 1,2872 & 0,8554 & \multirow{2}{*}{1,41} \\
\hline & High & 75 & 1,5455 & 1,3260 & \\
\hline
\end{tabular}

While 81 of 156 enterprises were audited by the audit companies other than Big Four audit companies, 75 enterprises were audited by the Big Four audit companies argued to provide a high quality audit service. $41 \%$ of the audit committees members of these 156 enterprises consisted of independent members. The ratio of 
independence of the boards of directors was $26 \%$. In other words, almost one of each 4 board members was independent $45 \%$ of total assets were financed by liabilities. That is to say, the equity values of 156 enterprises were higher than liabilities in average. This is something positive for both investors and enterprises.

The ratio of independence of the audit committees of 156 enterprises was $41 \%$. The ratio of independence of the audit committees of 75 enterprises audited by four big audit companies was $45 \%$ (0.4497). The ratio of independence of the audit committees of the enterprises audited by other audit companies was $39 \%$. As is seen, the ratio of independence of audit committees was higher among the enterprises audited by four big audit companies argued to provide a high quality audit service. Normally, it is expected for information asymmetry to decrease as the ratio of independence increases. Thus, there is a linear relationship between the quality of audit and information asymmetry. Contrary to expectations, the ratio of independence of the boards of directors of the enterprises audited by Big Four, which were argued to provide a high quality audit service, was found to be lower than that of others.

The highness of Altman Z-score, which shows the financial strength or weakness of an enterprise, is an indicator of lack of financial difficulty. However, the lowness of this score points to the existence of financial difficulty. If this score becomes too low, the enterprise may go bankrupt. As is seen in the table above, enterprises belonging to both groups do not experience any financial difficulty in average, but the above-mentioned ratio is higher among the enterprises subjected to a high quality audit process, i.e., these enterprises may go though less financial difficulty. The ratio of market value to book value, the ratio of short-term liabilities and long-term liabilities to total assets, and Tobin Q ratio are higher among the enterprises argued to be put into a high quality audit process.

Table 3. Differences between variables according to whether high/poor audit quality

\begin{tabular}{lllllll}
\hline & IAC & IBD & AZ & MV/BV & TL/TA & TQ \\
\hline Mann-Whitney U & 2733,500 & 2553,000 & 2668,500 & 2497,500 & 2795,000 & 2529,500 \\
$\mathbf{Z}$ & $-1,120$ & $-1,743$ & $-1,309$ & $-1,915$ &,- 860 & $-1,802$ \\
Level of Significance &, 263 &, 081 &, 191 &, 055 &, 390 &, 072 \\
(Asymp. Sig-2 tailed) & & & & & & \\
\hline
\end{tabular}

In table 3, it was observed whether there was any difference between the variables used for measuring information asymmetry in terms of the quality of audit. According to the table, 3 variables varied in terms of the quality of audit at the significance level of $10 \%$. These variables were the independence of the board of directors $(0.081)$, the ratio of market value to book value $(0.055)$, and Tobin Q $(0,072)$ ratio. Other three variables did not vary in terms of the quality of audit.

The collective interpretation of table 2 and table 3 provides results different from those observed in the literature. One of the variables found to be significant was the ratio of independence of the board of directors. According to the related literature, as the ratio of independence of the board of directors rises, information asymmetry decreases. Thus, it is expected for the enterprises with a high ratio of independence of the board of directors to have a high quality audit process. However, table 2 shows that the enterprises argued to have a high quality audit process had a board of directors with a lower ratio of independence. While the ratio of independence of the board of directors of the enterprises argued to have a high quality audit process was $25 \%$, the same ratio was $27 \%$ for other enterprises.

Another significant variable was the ratio of market value to book value. Literature review shows that markets values are higher than book values in enterprises where there is a high information asymmetry. Thus, it is expected for the ratio of market value to book value to be lower among the enterprises argued to have a high quality audit process in comparison to other enterprises. According to table 2, while the "market value/book value" average of the enterprises that had a high quality audit process was 3.961, the average of other enterprises was 1.9249. It was expected for the enterprises with a high quality audit process to have lower market value/book value average. However, a contrary finding was obtained here, too.

The third significant ratio was Tobin $\mathrm{Q}$ ratio. According to the studies in the literature, the highness of this ratio is an indicator of high-level information asymmetry. Thus, the expectation is that the enterprises with a higher quality audit process have a lower Tobin Q ratio. However, according to table 2, while the average Tobin Q ratio of the enterprises audited by 4 big audit companies was 1.5455 , that of other enterprises was found to be 1.2872 . A relationship contrary to the related literature was detected here, too. 


\section{Conclusion}

It is a fact that there is a relationship between the quality of audit and information asymmetry as well as the sub-variables used for measuring information asymmetry. According to this relationship, as the quality of audit increases, information asymmetry decreases. Thus, it is expected that there is an indirect relationship between the quality of audit and the information asymmetry variables found to be significant in this study. According to the related literature, this relationship can be summarized as follows: if the quality of audit is high, the board of directors has a high independence, the ratio of market value/book value is low, and Tobin Q ratio is low. However, the results of this study demonstrate that the exact opposite situation is true for the manufacturing industry enterprises traded at Istanbul Stock Exchange in terms of the above-mentioned three variables found to be significant. In brief, it would be expected that the manufacturing industry enterprises audited by Big Four audit companies, which are argued to provide a high quality audit service, have low information asymmetry. However, it was not the case. This may require investigating whether Big Four audit companies deemed to provide a high quality audit service really provide an audit service of higher quality than other audit companies in Turkey. On the other hand, it springs to mind that the audit companies apart from the aforesaid Big Four audit companies may provide an audit service of not lower quality than these companies. Therefore, the fact that Big Four audit companies provide a good audit service in other countries does not guarantee the same performance in Turkey.

\section{References}

Almutairi, A. R., Dunn, K. A., \& Skantz, T. (2009). Managerial Auditing Journal Emerald Article: Auditor Tenure, Auditor Specialization, and Information Asymmetry. Managerial Auditing Journal, 24(7), 600-623. http://dx.doi.org/10.1108/02686900910975341

Altman, E. I. (1968). Financial Ratios, Discriminant Analysis and the Prediction of Corporate Bankruptcy. The Journal of Finance, 23(4), 589-609. http://dx.doi.org/10.1111/j.1540-6261.1968.tb00843.x

Anglin, P., Edelstein, R., Gao, Y., \& Tsang, D. (2011). How Does Corporate Governance Affect the Quality of Investor Information? The Curious Case of REITs. JRER, 33(1), 1-23.

Berglund, T., \& Westerholm, P. J. (2010). Foreign Investors' Reaction to Lower Profitability-The Role of Information Asymmetry. International Review of Finance, 10(4), 455-483. http://dx.doi.org/10.1111/j.1468-2443.2010.01108.x

Brown, S., \& Hillegeist, S. H. (2007). How Disclosure Quality Affects The Level of Information Asymmetry. Review of Accounting Studies, September (12), 443-477.

Clarke, J., \& Shastri, K. (2000). On Information Asymmetry Metrics, Working Paper (pp. 1-58). Retrieved from http://papers.ssrn.com/sol3/papers.cfm?abstract_id $=251938$

Dunn, K. A., \& Mayhew, B. W. (2004). Audit Firm Industry Specialization and Client Disclosure Quality. Review of Accounting Studies, 9, 35-58. http://dx.doi.org/10.1023/B:RAST.0000013628.49401.69

Er, B. (2010). Halka Arzlarda Kâr Tahmini Ve Hisse Senedi Performansı İlişkisi: I.M.K.B. Uygulaması, Unpublished PhD Thesis, Karadeniz Teknik Üniversitesi, Sosyal Bilimler Enstitüsü, İsletme Anabilim Dal, İsletme Program1, Trabzon.

Fanning, K. M., \& Cogger, K. O. (1998). Neural Network Detection of Management Fraud Using Published Financial Data. International Journal of Intelligent Systems in Accounting, Finance \& Management, 7, 21-41. http://dx.doi.org/10.1002/(SICI)1099-1174(199803)7:1<21::AID-ISAF138>3.0.CO;2-K

Hakim, F., \& Omri, A. (2009). Audit Quality and Equity Liquidity: Case of the Listed Tunisian Firms. The IUP Journal of Audit Practice, VI(2), 57-72.

Jackson, L. A., Robinson, D., \& Shelton, S. W. (2009). The Association between Audit Committee Characteristics, The Contracting Process and Fraudulent Financial Reporting. American Journal of Business, 24(1), 57-65. http://dx.doi.org/10.1108/19355181200900005

Jones, K. (2004). Improving Fraud Risk Assessments through Analytical Procedures. Doctoral Dissertation, University of Arizona.

Karamanou, I., \& Vafeas, N. (2005). The Association between Corporate Boards, Audit Committees, and Management Earnings Forecasts: An Empirical Analysis. Journal of Accounting Research, 43(3), 453-486. http://dx.doi.org/10.1111/j.1475-679X.2005.00177.x

Kavut, L. (2001). Bağımsız Denetçiler İle Denetim Hizmeti Alan İsletmelerin Yöneticilerinin Denetim Kalitesine 
İlişkin Görüş ve Tutumları. IMKB Dergisi, 5(20), 1-30.

Knapp, C. A., \& Knapp, M. C. (2001). The Effects of Experience And Explicit Fraud Risk Assessment in Detecting Fraud With Analytical Procedures. Accounting, Organizations and Society, 26, 25-37. http://dx.doi.org/10.1016/S0361-3682(00)00005-2

Krishnan, G. V., \& Visvanathan, G. (2008). Does the SOX Definition of an Accounting Expert Matter? The Association between Audit Committee Directors' Accounting Expertise and Accounting Conservatism. Contemporary Accounting Research, 25(3), 827-57. http://dx.doi.org/10.1506/car.25.3.7

Krishnaswami, S., \& Subramaniam, V. (1999). Information Asymmetry, Valuation, And The Corporate Spin-Off Decision. Journal of Financial Economics, 53, 73-112. http://dx.doi.org/10.1016/S0304-405X(99)00017-3

Leuz, C., \& Verrecchia, R. E. (2000). The Economic Consequences of Increased Disclosure. Journal of Accounting Research, 38, 91-124. http://dx.doi.org/10.2307/2672910

Maddala, G. S. (1991). A Perspective on the Use of Limited-Dependent and Qualitative Variables Models in Accounting Research. The Accounting Review, 86(4), 788-807.

Maury, B. (2006). Family Ownership and Firm Performance: Empirical Evidence From Western European Corporations. Journal of Corporate Finance, 12, 321-341. http://dx.doi.org/10.1016/j.jcorpfin.2005.02.002

Muller, K. A., \& Riedl, E. J. (2002). External Monitoring of Property Appraisal Estimates and Information Asymmetry. Journal of Accounting Research, 40(3), 865-881. http://dx.doi.org/10.1111/1475-679X.00074

Palmrose, Z. V. (1988). An Analysis of Auditor Litigation and Audit Service Quality. Accounting Review, 63, $55-73$.

Paprocki, C., \& Stone, M. S. (2004). Is The Quality of Critical Accounting Policy Disclosures Lower For Companies With High Information Asymmetry? Working Paper, Retrieved from http://papers.ssrn.com/sol3/papers.cfm?abstract_id=594202\&download=yes, pp.1-25

Quan, L. (2007). Fraudulent Financial Reporting: Theory and Evidence. Journal of Modern Accounting and Auditing, 3(2), 12-14.

Russ, R. W., Achilles, W. W., \& Greenfiald, A. C. (2009). The Altman Z-Score Revisited. Journal of International Finance and Economics, 9(4), 59-73.

Simunic, D. A. (1990). Discussion of External Audit and Asymmetric Information. Auditing: A Journal of Practice \& Theory, 9, 243-248.

Vafeas, N. (2005). Audit Committees, Boards, and the Quality of Reported Earnings. Contemporary Accounting Research, 22(4), 1093-1122. http://dx.doi.org/10.1506/1QYN-2RFQ-FKYX-XP84

Varıcı, İ. (2011). Hile Riski Ve Denetçinin Sorumluluğu: Hile Riskinin Ölçülmesine Yönelik Bir Uygulama, Unpublished PhD Thesis, Karadeniz Teknik Üniversitesi, Sosyal Bilimler Enstitüsü, İşletme Anabilim Dalı, İşletme Programı, Trabzon.

Wang, S., \& Welker, M. (2011). Timing Equity Issuance in Response to Information Asymmetry Arising from IFRS Adoption in Australia and Europe. Journal of Accounting Research, 49(1), 257-307. http://dx.doi.org/10.1111/j.1475-679X.2010.00392.x

\section{Notes}

Note 1. Istanbul Stock Exchange decided to maintain its operations under the name of Borsa Istanbul as of the 6th of April 2013.

Note 2. People who are subordinate to an enterprise generally, and to any management level of this enterprise specifically.

Note 3. 1) Working Capital / Total Assets; 2) Retained Earnings / Total Assets; 3) Earnings before Interest and Tax (EBIT) / Total Assets; 4) Market Value of Equity / Book Value of Total Liabilities; 5) Sales / Total Assets.

Note 4. It can be calculated with the following formula: (Total Liabilities - Equity Book Value + Market Value of Equity)/Total Assets (Krishnaswami \& Subramaniam, 1999; Maury, 2006). The data section of Istanbul Stock Exchange provides Market Value/Book Value ratios. Thus, these ratios were extracted from Istanbul Stock Exchange. The inverse of the ratio provided in the literature (BV/MV) was used. As this ratio rises, information asymmetry is expected to increase, too. This is because; if there is a high information asymmetry, the market value of a company becomes higher than its book value depending on growth opportunities. 
Note 5. PWC, Deloitte, Ernst \& Young and KPMG.

\section{Copyrights}

Copyright for this article is retained by the author(s), with first publication rights granted to the journal.

This is an open-access article distributed under the terms and conditions of the Creative Commons Attribution license (http://creativecommons.org/licenses/by/3.0/). 